\title{
Analyses of International Scientific Collaboration in China University-Taking University of Electronic Science and Technology of China as an Exmaple
}

\author{
Yang WEN ${ }^{1, a,{ }^{*}}$ \\ ${ }^{1}$ Library of University of Electronic Science and Technology of China, Chengdu 611731, China \\ aweny@uestc.edu.cn \\ ${ }^{*}$ Corresponding author
}

Keywords: co-authored papers, science citation index (SCl), international scientific collaboration.

\begin{abstract}
International scientific collaboration plays an important role in scientific research. Papers as the results of international scientific collaboration can show the participates of the institution in international scientific collaboration. This paper analyzes the international collaboration of University of Electric science and Technology of China (UESTC), focusing on six aspects of the SCI co-author papers from 2009 to 2013, thus, the general growth, collaborative state, collaborative institution, subject categories, international collaborative index and relative citation impact.
\end{abstract}

\section{Introduction}

In the modern time when the globalization of science and technology is developing rapidly, the international scientific collaboration has become an important part of national development strategy. And for the university, the situation of the global collaboration on scientific research put forward the urgent requirement of collaboration, at the same time, it provides a good opportunity. International scientific collaboration has become one of the important strategy of promoting university scientific research level and influence. International scientific collaboration can absorb the wisdom of outstanding researchers and technical advantage, provide researchers with more abundant research ideas, methods and resources, improve the quality and quantity of scientific research output.

International co-authored paper is an important form of international collaboration in scientific research achievements, and also is an important indicator of international research ability.

\section{Method}

American information technology (ISI-Institute for Scientific Information) has famous Science Citation Index database (SCI) and is always been recognized as the world's most authoritative scientific and technical statistical and evaluation tools [1]. Based on 1726 papers in 2009- 2013, collected by the SCI database and co-authored by University of Electronic Science and Technology of China(UESTC) and their counterparts from other nations /regions, this paper analyses the performance of UESTC's international collaboration in the scientific research field.

\section{Results}

\section{Growth}

From the overall point of view, during 2009 to 2013, the number of international co-authored papers with UESTC shows a tendency of increase year by year. From Fig. 1, UESTC published 6954 international papers, among them the number of international co-authored papers is 1726 and increase from 208 in 2009 to 487 in 2013. The growth rate reached 134\%. At the same time, it indicates that the speed of international research collaboration of UESTC also increase year by year (see Fig.1). 


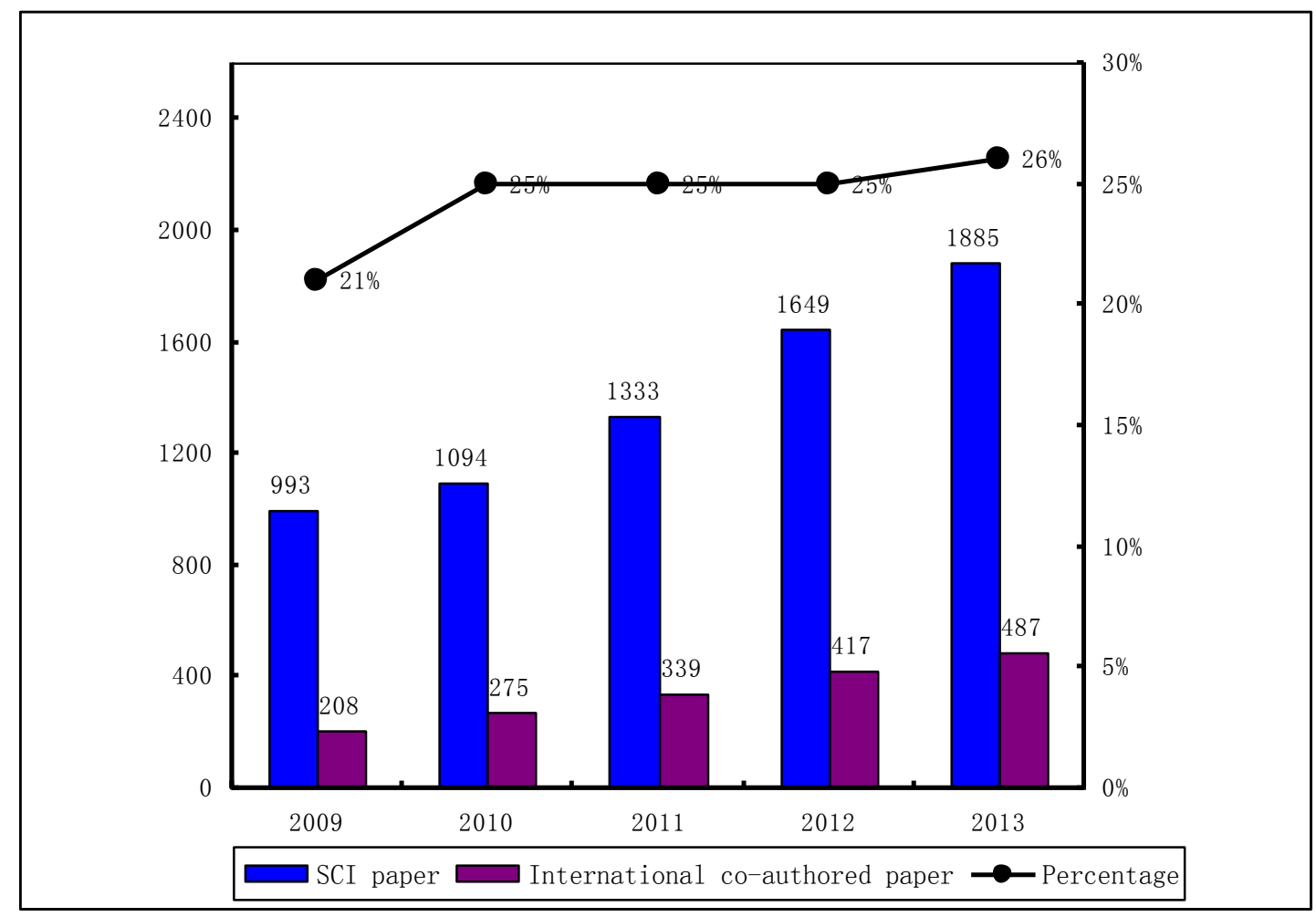

Fig.1 The growth of co-authored papers

\section{Collaborative Nations/ Regions}

In 2009-2013, UESTC carried out international collaboration on paper with 53 countries and regions and collaboration countries is mainly in developed countries. Among them, the number of international co-authored papers with United States is the most and reaches 817 during five years, accounting for $47 \%$ of total international co-authored papers of UESTC. This figure shows that the nearly half international co-authored papers of UESTC is completed with United States and is far higher than with Singapore in the second. UESTC has 241 international co-authored papers with Singapore.

Table1 Co-authored papers with different countries or regions

\begin{tabular}{|l|l|l|l|l|l|}
\hline Ranking & 2009 & 2010 & 2011 & 2012 & 2013 \\
\hline \multirow{2}{*}{1} & USA & USA & USA & USA & USA \\
\cline { 2 - 6 } & 106 & 137 & 155 & 192 & 227 \\
\hline \multirow{2}{*}{2} & Singapore & Singapore & Singapore & Singapore & Singapore \\
\cline { 2 - 6 } & 33 & 49 & 52 & 54 & 53 \\
\hline \multirow{2}{*}{3} & Canada & South Korea & England & Australia & Australia \\
\cline { 2 - 6 } & 15 & 17 & 26 & 37 & 38 \\
\hline 4 & Australia & England & Canada & Canada & Japan \\
\cline { 2 - 6 } & 13 & 15 & 19 & 27 & 34 \\
\hline 5 & England & Japan & Switzerland & South Korea & England \\
\cline { 2 - 6 } & 11 & 14 & 19 & 26 & 33 \\
\hline 6 & Germany & Switzerland & Japan & England & Canada \\
\cline { 2 - 6 } & 8 & 10 & 18 & 23 & 24 \\
\hline 7 & Japan & Canada & Australia & Japan & Israel \\
\cline { 2 - 6 } & 7 & 8 & 17 & 22 & 21 \\
\hline
\end{tabular}




\begin{tabular}{|l|l|l|l|l|l|}
\hline 8 & South Korea & France & Israel & Germany & Switzerland \\
\cline { 2 - 6 } & 6 & 8 & 14 & 11 & 16 \\
\hline \multirow{2}{*}{9} & Switzerland & Germany & Scotland & Israel & South Korea \\
\cline { 2 - 6 } & 5 & 7 & 8 & 11 & 15 \\
\hline 10 & Italy & Australia & South Korea & Norway & Germany \\
\cline { 2 - 6 } & 4 & 6 & 8 & 9 & 14 \\
\hline
\end{tabular}

From Table1 the characteristics of UESTC with collaboration nations and regions can be seen:

(i) From 2009-2013, the annual co-authored papers with United States held in the first because United States is the position of today's world center of science and technology.

(ii) UESTC has extensive international collaboration with other countries and regions and the international collaboration countries and regions with UESTC are mainly in western developed countries.

(iii) Partner in Asia, mainly in Singapore, Japan and South Korea, among them the most closely collaboration country is Singapore. Annual number of co-authored papers with Singapore ranks second in all international collaboration countries and regions.

(iv) In Singapore Chinese account for the vast majority of the population and overseas Chinese scholars play a bridging role of international cooperation in these papers. It was known as "Chinese phenomenon"[2].

\section{Collaborative Institutions}

In 2009-2013, the collaboration institutes with UESTC is mainly in universities and research institutes, as shown in Table2, it can be seen in collaboration with UESTC. The top five institutions by the maximum number of papers is Nanyang Technological University, National University of Singapore, Pacific Northwest National Laboratory, University of Fribourg and Israeli Electricity Company and they have 387 international co-authored papers with UESTC. Among them Nanyang Technological University has the most co-authored papers with UESTC and the number of co-authored papers reach 128. There is no lack of famous university in the world with UESTC, such as Duke University, University of Michigan and University of California, Los Angeles. They are all the world's top 50 well-known university [3].

Table2 Co-authored papers with different collaborative institutions

\begin{tabular}{|c|c|c|c|c|c|}
\hline Ranking & 2009 & 2010 & 2011 & 2012 & 2013 \\
\hline 1 & $\begin{array}{l}\text { Nanyang } \\
\text { Technological } \\
\text { University }\end{array}$ & $\begin{array}{l}\text { Nanyang } \\
\text { Technological } \\
\text { University }\end{array}$ & $\begin{array}{l}\text { Nanyang } \\
\text { Technological } \\
\text { University }\end{array}$ & $\begin{array}{l}\text { Nanyang } \\
\text { Technological } \\
\text { University }\end{array}$ & $\begin{array}{l}\text { Nanyang } \\
\text { Technological } \\
\text { University }\end{array}$ \\
\hline 2 & $\begin{array}{l}\text { Pacific Northwest } \\
\text { National Laboratory }\end{array}$ & $\begin{array}{c}\text { Nanyang } \\
\text { Technological } \\
\text { University }\end{array}$ & $\begin{array}{c}\text { Nanyang } \\
\text { Technological } \\
\text { University }\end{array}$ & $\begin{array}{c}\text { National } \\
\text { University of } \\
\text { Singapore }\end{array}$ & $\begin{array}{l}\text { Israel Elect } \\
\text { Corp Ltd }\end{array}$ \\
\hline 3 & $\begin{array}{l}\text { University of } \\
\text { Delaware }\end{array}$ & $\begin{array}{c}\text { Pacific Northwest } \\
\text { National } \\
\text { Laboratory } \\
\end{array}$ & $\begin{array}{l}\text { University of } \\
\text { Fribourg }\end{array}$ & $\begin{array}{l}\text { University of } \\
\text { Arkansas }\end{array}$ & $\begin{array}{c}\text { National } \\
\text { University of } \\
\text { Singapore }\end{array}$ \\
\hline 4 & $\begin{array}{l}\text { University of } \\
\text { Michigan }\end{array}$ & $\begin{array}{l}\text { University of } \\
\text { Fribourg }\end{array}$ & $\begin{array}{l}\text { Israel Elect Corp } \\
\text { Ltd }\end{array}$ & $\begin{array}{l}\text { University of } \\
\text { Michigan }\end{array}$ & $\begin{array}{l}\text { University of } \\
\text { Fribourg }\end{array}$ \\
\hline 5 & $\begin{array}{l}\text { University of } \\
\text { Nebraska }\end{array}$ & $\begin{array}{c}\text { Chungnam } \\
\text { National } \\
\text { University } \\
\end{array}$ & $\begin{array}{c}\text { Pacific Northwest } \\
\text { National } \\
\text { Laboratory } \\
\end{array}$ & $\begin{array}{r}\text { Israel Elect Corp } \\
\text { Ltd }\end{array}$ & $\begin{array}{l}\text { University of } \\
\text { Queensland }\end{array}$ \\
\hline 6 & Duke University & $\begin{array}{c}\text { University of } \\
\text { California, Los } \\
\text { Angeles }\end{array}$ & $\begin{array}{c}\text { University of } \\
\text { Arkansas }\end{array}$ & $\begin{array}{l}\text { University of } \\
\text { Queensland }\end{array}$ & $\begin{array}{c}\text { Pacific } \\
\text { Northwest } \\
\text { National } \\
\text { Laboratory } \\
\end{array}$ \\
\hline 7 & $\begin{array}{l}\text { University of } \\
\text { Liverpool }\end{array}$ & $\begin{array}{l}\text { University of } \\
\text { Michigan }\end{array}$ & $\begin{array}{l}\text { University of } \\
\text { Delaware }\end{array}$ & Duke University & Duke University \\
\hline
\end{tabular}




\begin{tabular}{|c|c|c|c|c|c|}
\hline 8 & $\begin{array}{c}\text { Inst Mat Res \& } \\
\text { Engn IMRE, } \\
\text { Singapore }\end{array}$ & Lehigh University & $\begin{array}{c}\text { University of } \\
\text { Tennessee }\end{array}$ & $\begin{array}{c}\text { Pacific Northwest } \\
\text { National } \\
\text { Laboratory }\end{array}$ & $\begin{array}{c}\text { Newcastle } \\
\text { University }\end{array}$ \\
\hline 9 & $\begin{array}{c}\text { University of } \\
\text { California, Los } \\
\text { Angeles }\end{array}$ & Duke University & $\begin{array}{c}\text { University of } \\
\text { California, Los } \\
\text { Angeles }\end{array}$ & $\begin{array}{c}\text { University of } \\
\text { Nebraska }\end{array}$ & $\begin{array}{c}\text { Monash } \\
\text { University }\end{array}$ \\
\hline 10 & $\begin{array}{c}\text { University of } \\
\text { Fribourg }\end{array}$ & $\begin{array}{c}\text { University of } \\
\text { Delaware }\end{array}$ & $\begin{array}{c}\text { University of } \\
\text { Nebraska }\end{array}$ & $\begin{array}{c}\text { University of } \\
\text { Fribourg }\end{array}$ & $\begin{array}{c}\text { University of } \\
\text { Alberta }\end{array}$ \\
\hline
\end{tabular}

\section{Collaboration in Different Subjects}

The international co-authored papers of UESTC are 1726 and in 129 subjects, among them, the international co-authored papers of 504 are in the subject of engineer electrical electronic, occupying the first place. The second is the subject of physics applied, and then the subject of telecommunications.

In order to research differences in the levels of international collaboration of UESTC in the interdisciplinary field, this paper use the international collaborative index (ICI) to analyze the international collaboration activity of UESTC in different subjects [4].

Here ICI = (Ii / Iio) / (Io /Ioo) where

$\mathrm{Ii}=$ Number of internationally co-authored papers for institution $\mathrm{i}$,

Iio $=$ Total output for institution $\mathrm{i}$,

Io $=$ Number of internationally co-authored papers for all institutions,

Ioo $=$ Total output for all institutions.

The value of ICI $=1$ indicate that a institution's collaborative effort corresponds to subject average. ICI $>1$ reflects collaboration higher than subject average and ICI $<1$ reflects collaboration less than subject average.

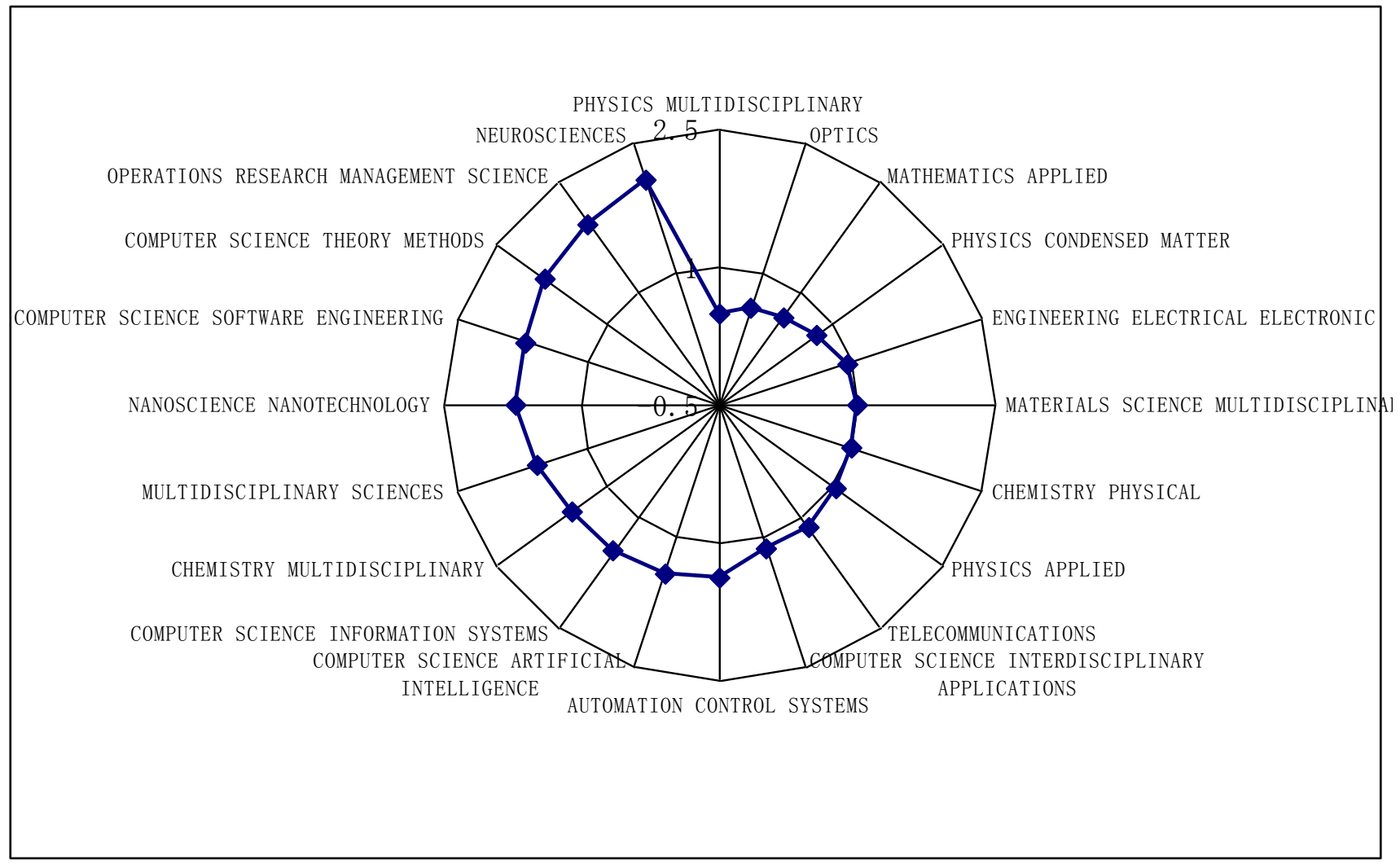

Fig. 2 The ICI of UESTC in Top 20 subjects

From Fig. 2 the ICI $>1$ of UESTC in Top 20 subjects in 2009-2013 has the subject of materials science multidisciplinary, chemistry physical, physics applied, telecommunications, computer science interdisciplinary applications, automation control systems, computer science artificial 
intelligence, computer science information systems, chemistry multidisciplinary,multidisciplinary sciences, nanoscience nanotechnology, computer science theory methods ,operations research management science and neurosciences. It illustrate that the international collaboration activity in these subjects is strong. The ICI $<1$ is in these subjects that engineering electrical electronic, physics condensed matter, mathematics applied, optics and physics multidisciplinary. It Illustrate that these subjects disciplines international cooperation level lower than the average level of international cooperation, school the least active in the international research collaboration.

From the previous data we can see the overall number of international co-authored papers of UESTC in five years is increasing year by year. But the quality or influence of these international co-authored papers also need to pay attention. In this case, the quality of international co-authored papers of UESTC will be analyzed for further.

In bibliometrics, the citation of paper is an important index to evaluate the quality of the paper [5]. If the paper cited frequency is higher, the paper's quality or the greater If the number of citation is more, then the influence of the paper is greater.

This paper use the relative citation impact(RCI) to analyze the quality of international co-authored papers of UESTC in different subjects. RCI is a relative index. It can reflect the quality of international co-authored papers in a given subject at the same time eliminate the disadvantages of the different citation due to the various subject and citation habits.

For institution $\mathrm{i}$ let total papers be $\mathrm{P}_{\mathrm{i}}$ and citations $\mathrm{C}_{\mathrm{i}}$. The share of the institution's papers is then $\mathrm{P}_{\mathrm{i}}=\mathrm{P}_{\mathrm{i}} / \mathrm{P}$, where $\mathrm{P}=\sum \mathrm{P}_{\mathrm{i}}$ is the institution's total number of papers. Similarly, citation share is $\mathrm{C}_{\mathrm{i}}=\mathrm{C}_{\mathrm{i}} / \mathrm{C}$, with $\mathrm{C}=\sum \mathrm{C}_{\mathrm{i}}$. Here $\mathrm{RCI}_{\mathrm{i}}=\mathrm{C}_{\mathrm{i}} / \mathrm{P}_{\mathrm{i}}=\left(\mathrm{C}_{\mathrm{i}} / \mathrm{P}_{\mathrm{i}}\right)(\mathrm{P} / \mathrm{C})[6]$.

The value of $\mathrm{RCI}=1$ indicate that a institution's citation per collaborative paper corresponds to subject average. RCI $>1$ reflects a institution's citation per collaborative paper higher than subject average and RCI $<1$ reflects a institution's citation per collaborative paper less than subject average.

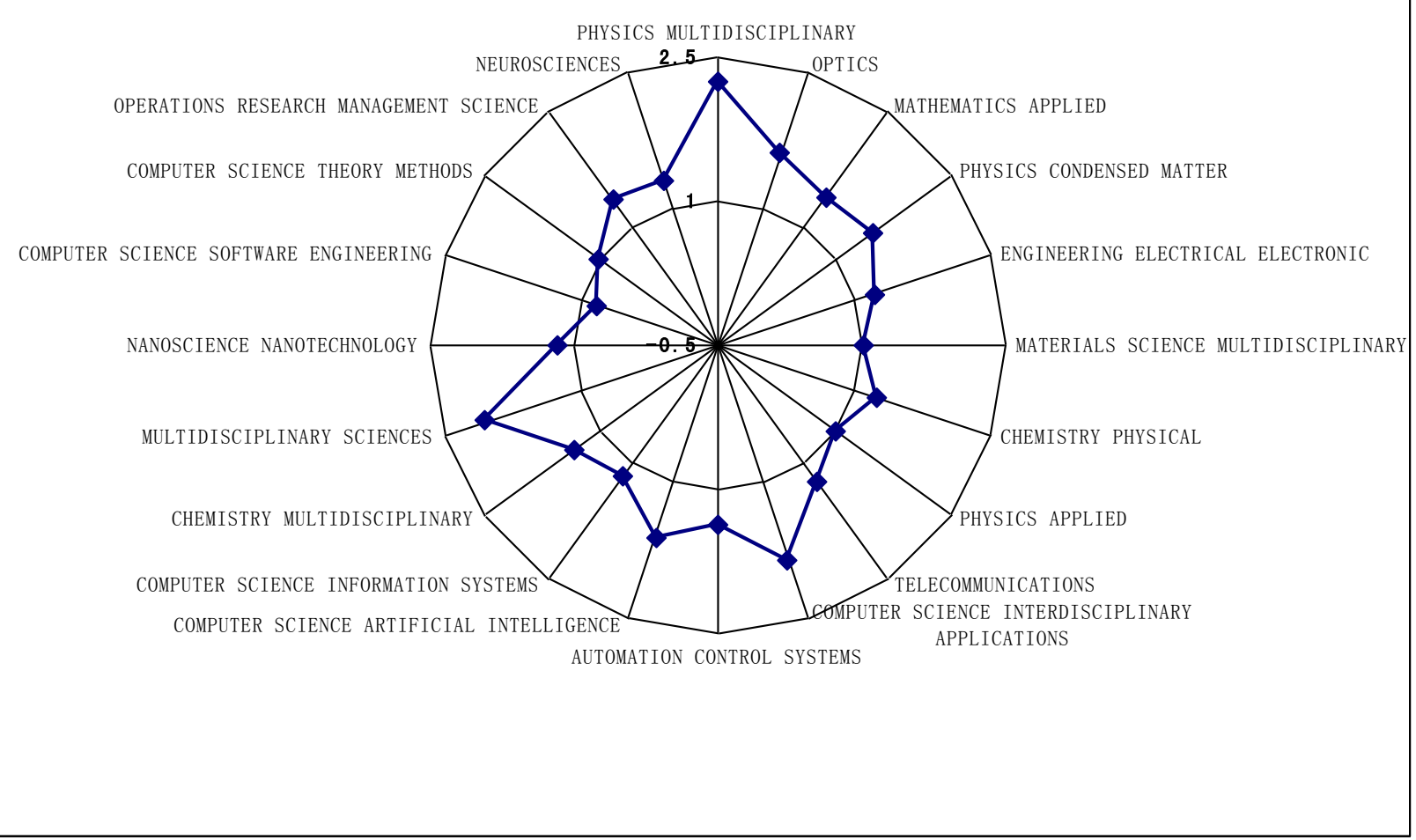

Fig. 3 The RCI of UESTC in Top 20 subjects

From Fig.3, the quality of international co-authored papers of UESTC in different subjects has 
different comparative advantage. Ranking in five former subjects is physics multidisciplinary, multidisciplinary sciences, computer science interdisciplinary applications, computer science artificial intelligence and optics.

The international co-authored papers in the subject of physics multidisciplinary showed the most prominent influence because these international co-authored papers are published in famous journals with high impact factor, such as Physical Review Letters(IF,7.943) and New Journal of Physics(IF,4.063).

\section{Conclusions}

Overall, the number of international co-authored paper of UESTC from 2009 to 20013 presents growth trend, and the international collaboration countries and regions with UESTC are mainly in western developed countries. In Asia Singapore, Japan and South Korea have more international collaboration with UESTC, and Singapore plays an important role of collaboration.

Among the international collaboration institutions, the number of international co-authored paper with Nanyang Technological University is the largest.

Different subject presents a different collaborative state, among them the subjects of operations research management science and neurosciences are the most active international collaboration. Physics multidisciplinary, multidisciplinary sciences, computer science interdisciplinary applications, computer science artificial intelligence and optics have a comparative advantage in the influence of international co-authored paper.

Based on the international co-authored papers of UESTC from 2009 to 2013, this paper analyzes the future development of university and put forward the following suggestions:

We should seek the partner with high research level and strengthen the depth of collaboration with world-class universities, research institutions and enterprises. It will promote the share of resources and improve the original research ability and academic creativity of universities.

Through the deep collaboration with the high level partners, the number of international collaboration projects will increase and be conducive to increase the number of international co-author papers and improve the scientific research and academic influence of university in international collaboration.

To reward the international co-authored paper. Universities enhance the focus on the number of papers at the same time, more should pay attention to improve the quality of the paper, so universities in the formulation of reward policy when considering the number of papers at the same time, and should be considered citations and impact factor (IF) of academic journal. It will encourage teachers to select for high impact factor of academic journals. The paper that was published in high level of academic journals will promote the international academic influence of universities.

Improving the system of introducing talents, especially the excellent teacher attaches great importance to the introduction of overseas study experience. The introduction of teachers will bring new vitality to the scientific research of universities. Generally teachers with overseas study experience will still maintain a connection with collaborative researchers in overseas. At the same time, they have an advantage in the field of writing with foreign language, and these will promote the output of international collaboration paper.

Strengthen and expand international collaboration mode in training. Through sending a large number of teachers to study abroad and taking the joint training in students with foreign universities, university has set up a platform for international scientific collaboration and build a positive scientific research atmosphere. Teachers and doctoral graduates during the period of studying abroad, will be involved in the research activities of the host countries, this also is helpful for the growth of international co-authored paper of universities. 


\section{References}

[1] Jin Ju, Wu Yishan, Liang Zhanping, A Summary of Bibliometric Study on International Science and Technology Cooperation, Library and Information Service. 03 (2007) 63-67.

[2] Jin Bihui, Zhang Wang, Zhou Qiuju, Yang Liying, Yang Liangbin, Wang Dan, The Internaional S\&T Collaboration of China: The Overses Chinese Phenomenon, Science Focus. 06 (2007) 20-27.

[3] Information on http://www.shanghairanking.cn

[4] Garg KC, Padhi P., A Study of Collaboration in Laser Science and Technology, Scientomatrics. 51 (2001) 415-427.

[5] Huang Ningyan, Wu Yishan, A comparative study over S \& $\mathrm{T}$ output indicators between mainland China and Taiwan region, Studies in Science of Science.06 (2002) 604-607.

[6] He Tianwei. Scientometric indication of Chinese SCI papers with international collaboration, Bulletin of National Natural Science Foundation of China. 02 (2009) 93-97. 